\title{
Daily activity and diet of Talaud bear cuscus (Ailurops melanotis Thomas, 1898) on Salibabu Island, North Sulawesi, Indonesia
}

\author{
TERRI REPI ${ }^{1,2, \boldsymbol{v}}$, BURHANUDDIN MASYUD ${ }^{3}$, ABDUL HARIS MUSTARI ${ }^{3}$, LILIK BUDI PRASETYO ${ }^{3}$ \\ ${ }^{1}$ Program of Tropical Biodiversity Conservation, Graduate School. Institut Pertanian Bogor. Jl. Raya Dramaga, Kampus IPB Dramaga, Bogor 16680, \\ West Java, Indonesia \\ ${ }^{2}$ Department of Animal Husbandry, Universitas Muhammadiyah Gorontalo. J1. Prof. Dr. H. Mansoer Pateda, Gorontalo 96181, Gorontalo, Indonesia. \\ Tel./fax.: +62-271-663375, `email: terrirepi@gmail.com \\ ${ }^{3}$ Department of Forest Resources, Conservation and Ecotourism, Institut Pertanian Bogor. Jl. Raya Dramaga, Kampus IPB Dramaga, Bogor 16680, West \\ Java, Indonesia
}

Manuscript received: 15 July 2019. Revision accepted: 22 August 2019.

\begin{abstract}
Authors. 2019. Daily activity and diet of Talaud bear cuscus (Ailurops melanotis Thomas, 1898) on Salibabu Island, North Sulawesi, Indonesia. Biodiversitas 20: 2636-2644. Talaud bear cuscus (Ailurops melanotis) is an endemic species in the Sangihe and Talaud Islands, North Sulawesi, Indonesia. This species is critically endangered in the IUCN Redlist, with a declining population trend. As a protected species in Indonesia, there has not been any specific research on this species. This research aimed to determine the daily activity pattern of talaud bear cuscus based on sex and age classes, and provide the first preliminary data on its dietary diversity and preference. Data collection was conducted on Salibabu Island (Talaud Islands District, North Sulawesi, Indonesia) for approximately three months (May-July 2016). The talaud bear cuscus spent most of its time resting 78.19\%, moving 14.98\%, feeding 3.49\%, grooming $3.06 \%$, and social $0.28 \%$. Talaud bear cuscus fed on 22 species in its daily diet consisting of 20 tree species and 2 liana species. Cuscus fed mainly on young leaves (57.48\%) followed by petioles (leaf stalk) (17.60\%), mature leaves (15.33\%), bud (7.19\%), flowers (1.32\%) and unripe fruit $(1.07 \%)$. This preliminary data about the behavior, activity patterns, and diet of talaud bear cuscus, in general, can be used as supporting information in cuscus conservation efforts, especially habitat management related to the availability of feed resources and to determine the time of the survey and to understand the general behavior and ecology of this species.
\end{abstract}

Keywords: Daily activity pattern, Ailurops melanotis, daily activity, diet, feeding preferences, time budget

\section{INTRODUCTION}

Phalangeridae as an arboreal marsupial family consists of 29 currently recognized species in six genera and widely distributed across Australia, New Guinea, eastern Indonesia, and surrounding islands (Ruedas and Morales 2005; Helgen and Jackson 2015). According to Kealy (2018), the wide distribution and diversity in the family Phalangeridae caused a lack of information at the level of species in this family. One of the species in this family that are poorly understood is Ailurops melanotis (Heinsohn 2010; Flannery and Helgen 2016; Nowak 2018).

Talaud bear cuscus (Ailurops melanotis) was previously considered a subspecies (Ailurops ursinus melanotis) of Sulawesi bear cuscus (Ailurops ursinus). This species then listed as separated species based on morphological distinction, especially coloration (Groves 2005: Helgen and Jackson 2015) (Figure 1). This species is an endemic in the Talaud Islands, North Sulawesi and is only found on Salibabu Island (Wilson and Reeder 2005; Flannery and Helgen 2016). This species is highly hunted and continues to decline. Its populations distributed in fragmented habitats due to forest degradation and loss by logging, agricultural expansion, and human settlements (Riley 2002). According to the International Union for Conservation of Nature (IUCN), these species are listed as Critically Endangered with a declining population trend, and in 2014 was assigned to Appendix I by the Convention on International Trade in Endangered Species of Wild Fauna and Flora (CITES).

As a protected species in Indonesia, there have not been any studies on the behavioral ecology of talaud bear cuscus that have ever been carried out, in fact, there are no scientific publications that contain photos of this species (Smith et al. 2012). Research on talaud bear cuscus is only limited to general surveys and literature studies (Riley 2002; Heinsohn 2010; Smith et al. 2012; Flannery and Helgen 2016). Thus it is important to conduct research on the behavioral ecology of this species in particular, as preliminary information for the conservation efforts of this species.

Research on animal behavior can make a major contribution to conservation efforts (Sutherland 1998) and can be used specifically as a tool to achieve conservation goals (Reed 2002). In general, animal behavior is related to two things: time budget/time allocation and activity patterns. Time budget is a description and quantification of how animals divide the time available between their activities (Breed and Moore 2012). The time budget is used to measure the amount of time that animals use in carrying out various types of activities (Milis et al. 2010). While the activity pattern is a number of activities carried out by animals in a certain time dimension. By knowing the pattern of distribution of activities, researchers can find out 
when animals engage in certain activities. Activity patterns and time budget are two important aspects of animal behavior that can be used to investigate ecological influences on individual behavior, comparison of activity patterns and time allocation in different ecological conditions allows researchers to explore ecological influences on animal behavior, and behavioral strategies (Zhou et al. 2007). This research aimed to determine the time budget and describe the activity pattern of talaud bear cuscus and provide the first preliminary data on its dietary diversity and preference.

\section{MATERIALS AND METHODS}

\section{Study area}

Data collection was conducted on Salibabu Island, which is administratively included in the Talaud Islands District, North Sulawesi, Indonesia (296 km from Sulawesi main Island) (Figure 2). This island is $89.97 \mathrm{~km}^{2}$, with an elevation of 0-335 meters above sea level. There is no protected area on this Island, all existing forests have the status of other use areas, with an area of secondary dryland forest remaining of approximately $14.40 \mathrm{~km}^{2}$. This research was conducted in the secondary dryland forest area, with an elevation of 98-140 meters above sea level, for approximately three months (May-July 2016).

\section{Data collection and analyses}

Observation of activity was carried out using the focal animal sampling method (Altmann 1974), by following the individual target and recording its activity and duration from 06.00 to 18.00. Data collection used instantaneous sampling with an interval of 1 minute. Observations were divided into 3 periods: morning (06.00-10.00), mid-day (10.01-14.00) and afternoon (14.01-18.00). Before data collection, habituation is carried out for approximately 1 month by following the target individual.

Cuscus was classified as adult males, adult females, and subadult, no individual infant was found in the observation. Adult males were identified based on large body size and prominent genital signs, in this case, the testicles and scrotum, adult females were identified based on large size and absence of prominent genital signs (testicles and scrotum), presence of adult males or presence of infant, subadult generally have smaller body sizes than adult males and females usually still live with adult males and females (Dwiyahreni et al. 1999).

Behavior was categorized into 5 activities: resting, moving, feeding, grooming, and social. Resting activities include silent activities without movement, sleeping, standing still, sitting still, sitting while moving the head, tail, hands, and leg but not moving. Moving activities included walking or moving positions. Feeding activities included taking food and putting it in the mouth, biting, chewing and swallowing. Grooming activities included scratching and cleansing of impurities in the individual fur (auto grooming). Social activities included mutual grooming (allogrooming), nursing, or being nursed and playing behavior (Dwiyahreni et al. 1999).

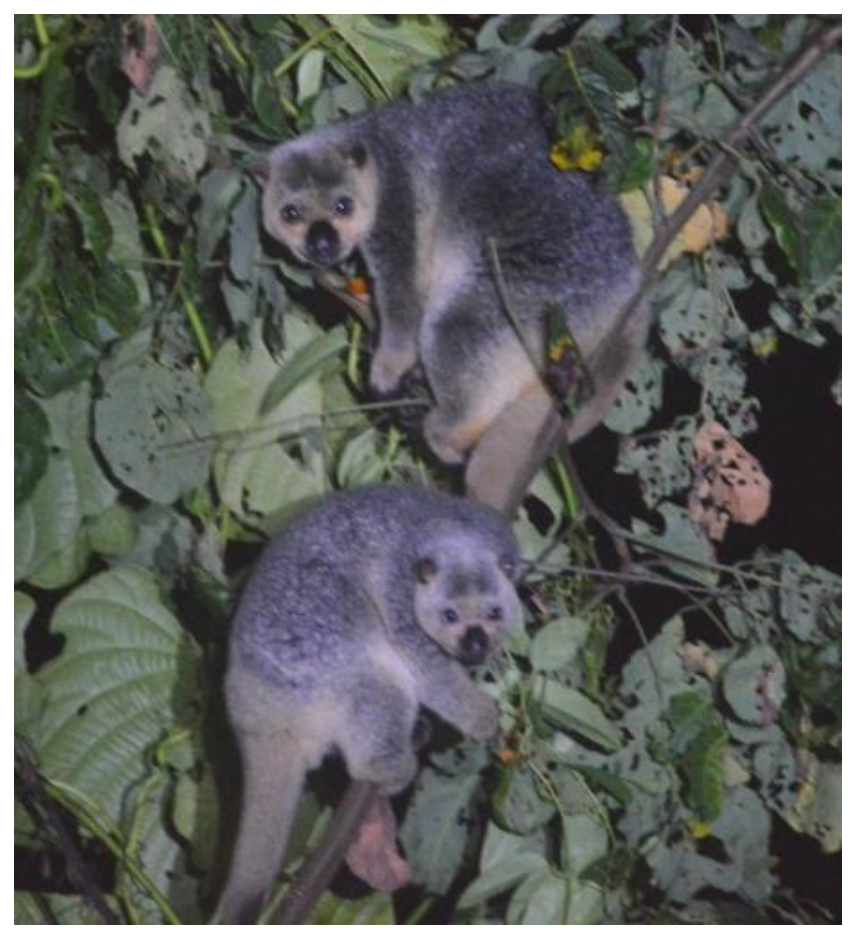

Figure 1. Adult female and sub-adult of Ailurops melanotis

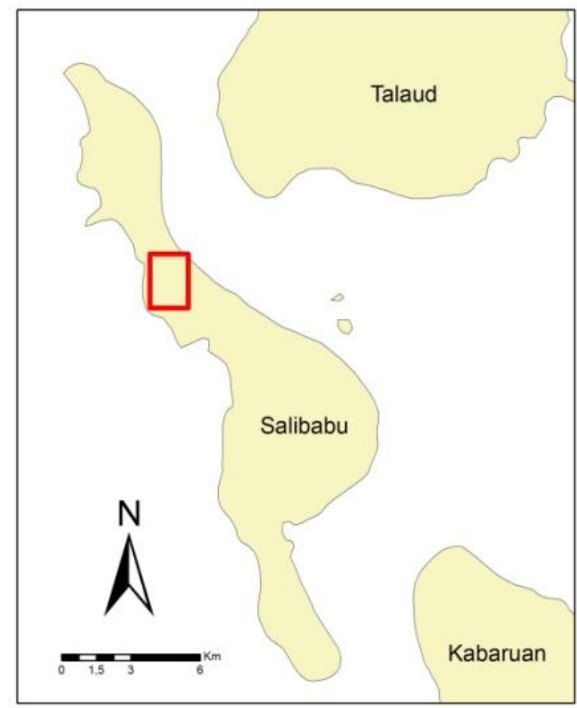

: Research

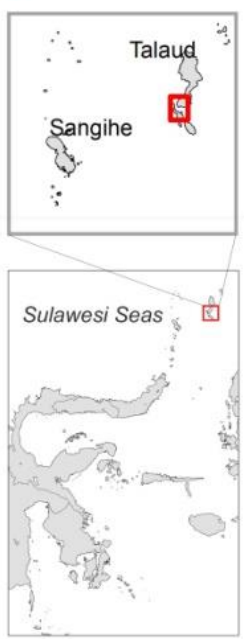

Figure 2. The map of study area of Ailurops melanotis in

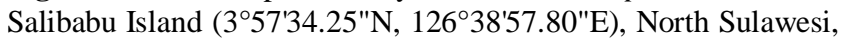
Indonesia

Feeding data collection was carried out using the focal animal sampling method (Altmann 1974) by recording the type of diet consumed by the individual target. Data collection was carried out for each sex and age classes. The data collected is the type of diet (plant species), parts ate (fruit, leaves, flowers, etc.), feed descriptions (young leaves, old leaves, young fruit, ripe fruit, buds, etc.), and the amount of consumption of each type of diet (Dwiyahreni et al 1999). Vegetation analysis using a sample plot in the form of line compartment method, with a 
total of 15 plots ( $20 \mathrm{~m}$ x $20 \mathrm{~m}$ ) was carried out to determine the diversity of vegetation species as well as the type of diet available at the study site. We also collected temperature and humidity data during the study in 3 periods; morning (06.00-07.00), afternoon (12.00-13.00) and afternoon (17.00-18.00).

Analysis of time budget is done by calculating the frequency and duration of time needed in each activity, presenting data in the form of tables and pie charts. For the analysis of the distribution of temporal activity patterns carried out qualitatively, through the presentation of tables and graphs of activity distribution within a certain time. Feeding analysis was carried out quantitatively, through the presentation of tables and pie charts, which explained the type, amount, parts eaten and the average amount of time for consumption of each type of dietary items. To find out differences in activity by age and sex, the Kruskal-Wallis test was used. To determine the significance of differences in behavior using the Mann Whitney $U$ test. Data processing uses Microsoft Excel, and Statistical Product and Service Solutions (SPSS) program version 25.0.

\section{RESULTS AND DISCUSSION}

\section{Time budget and activity pattern}

Activity observation was carried out for 252.35 hours in each age and sex class. Data collection was performed on individuals who had been followed for approximately 1 month (1 adult female and 1 sub-adult). While male individuals, although not identified as the same individuals, because often disappear from the habituation and data collection process, we assume are the same individuals, because in the area of observation we did not find other male individuals. In this study cuscus were often found in pairs or groups (three individuals), with frequencies of encounters; in pairs: 33 times, in groups: 19 times and solitary: 11 times. Adult males were the most commonly found solitary (7 times). Kuskus used an average vegetation height of $12.39 \mathrm{~m} \pm 3.37 \mathrm{SD}$.

Overall, the Talaud bear cuscus spent the most time to rest $78.19 \%$, moving $14.98 \%$, feeding $3.49 \%$, grooming $3.06 \%$, and social $0.28 \%$ (Figure 3). The time budget based on age and sex class showed differences (Figure 4.B), this was indicated by the Kruskal-Wallis test which showed significant differences in feeding, moving, resting and social activities (Table 1). Further tests using Mann Whitney $U$ showed a significantly higher time allocation for subadult feeding activity than adult males $(\mathrm{P}=0.004)$, as well as moving activity $(\mathrm{P}=0.004)$, on the contrary, resting activity in adult males was significantly higher than subadult $(\mathrm{P}=0.017)$. In social activities, the time budget of adult females was significantly higher than in adult males $(\mathrm{P}=0,000)$. Daily observations show the distribution of bear cuscus activity differs according to time period (Table 2 ). The talaud bear cuscus spends the highest rest time during the day $(82.96 \%)$, moves highest in the afternoon $(17.70 \%)$, feeding the highest in the afternoon $(4.81 \%)$, grooming is highest in the morning $(3.26 \%)$ and the highest social activity in the afternoon $(0.45 \%)$ (Figure $4 . \mathrm{A})$.

Based on the daily pattern activities, it can be seen that moving activities were increased in the morning and declined during the day, then showed an increase in the afternoon. Feeding activities tend to follow moving activities, then followed by resting activities, cuscus was moving when foraging, and resting afterward. The highest feeding activity in the morning is recorded at 07: 30-09: 30 and in the afternoon at 15: 30-17: 30 . We display the percentage of time used in every 30 minutes to show the pattern of daily activities (Figure 5.A-C).

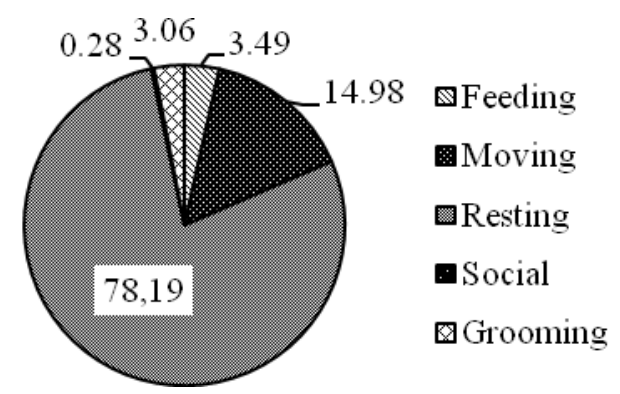

Figure 3. The percentage of the total daily activity of Ailurops melanotis on Salibabu Island, North Sulawesi, Indonesia

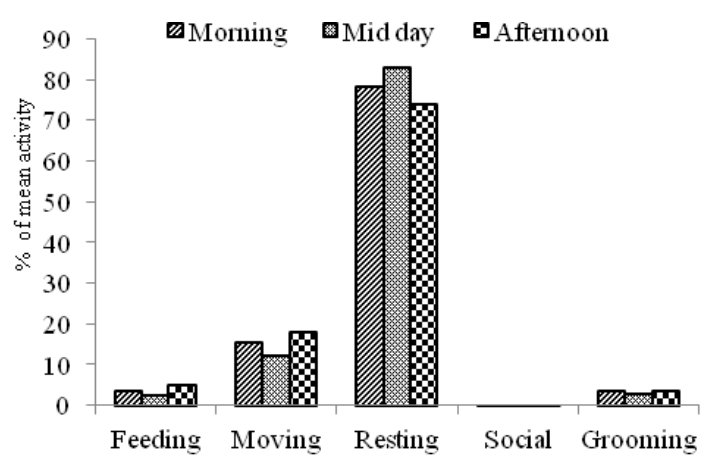

A

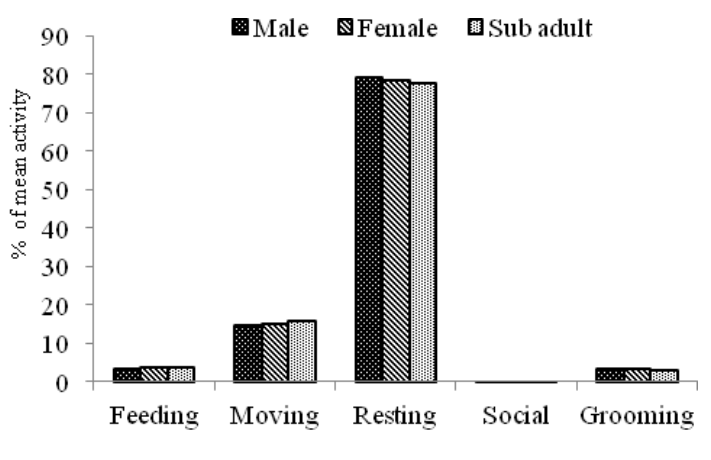

B

Figure 4. Percentage of activity spent by Ailurops melanotis in five behavioral categories according to (A) time of day and (B) age-sex class 
Table 1. Comparison of time budget of Ailurops melanotis

\begin{tabular}{lcccc}
\hline \multirow{2}{*}{ Activities } & \multicolumn{2}{c}{ Proportion of time spent $($ mean \pm SD) } & Different time budget between all age-sex class \\
\cline { 2 - 4 } & Female & Male & Sub-adult & \\
\hline Feeding & $25 \pm 3.30$ & $23.57 \pm 3.30$ & $26.90 \pm 3.51$ & $\chi 2=9.09 ; \mathrm{df}=2 ; \mathrm{P}=0.011^{*}$ \\
Moving & $107.62 \pm 7.92$ & $103.76 \pm 8.37$ & $112.67 \pm 9.29$ & $\chi 2=9.08 ; \mathrm{df}=2 ; \mathrm{P}=0.011^{*}$ \\
Resting & $563.48 \pm 11.48$ & $569.33 \pm 13.35$ & $558.48 \pm 13.90$ & \\
Social & $3.05 \pm 1.77$ & $0.90 \pm 1.55$ & $2.14 \pm 2.06$ & $\chi 2=6.70 ; \mathrm{df}=2 ; \mathrm{P}=0.040^{*}$ \\
Grooming & $20.81 \pm 2.63$ & $23.43 \pm 4.24$ & $20.81 \pm 3.40$ & $\chi 2=12.35 ; \mathrm{df}=2 ; \mathrm{P}=0.02^{*}$ \\
\hline
\end{tabular}

Note: * significantly different

Table 2. Comparison of activities based on time period of Ailurops melanotis

\begin{tabular}{lcccc}
\hline \multirow{2}{*}{ Activities } & Kruskal-Wallis test & & Mann Whitney U test \\
\cline { 3 - 5 } & (time period: morning, mid-day and afternoon) & Morning-mid day & Morning-afternoon & Mid day-afternoon \\
\hline Feeding & $\chi^{2}=31.80 ; \mathrm{df}=1 ; \mathrm{P}=0.000^{*}$ & $\mathrm{P}=0.010^{*}$ & $\mathrm{P}=0.000^{*}$ & $\mathrm{P}=0.000^{*}$ \\
Moving & $\chi 2=34.99 ; \mathrm{df}=1 ; \mathrm{P}=0.000^{*}$ & $\mathrm{P}=0.000^{*}$ & $\mathrm{P}=0.002^{*}$ & $\mathrm{P}=0.000^{*}$ \\
Resting & $\chi^{2}=36.51 ; \mathrm{df}=1 ; \mathrm{P}=0.000^{*}$ & $\mathrm{P}=0.000^{*}$ & $\mathrm{P}=0.000^{*}$ & $\mathrm{P}=0.000^{*}$ \\
Social & $\chi 2=4.093 ; \mathrm{df}=1 ; \mathrm{P}=0.043^{*}$ & $\mathrm{P}=0.428$ & $\mathrm{P}=0.006^{*}$ & $\mathrm{P}=0.043$ \\
Grooming & $\chi 2=13.89 ; \mathrm{df}=1 ; \mathrm{P}=0.000^{*}$ & $\mathrm{P}=0.000^{*}$ & $\mathrm{P}=0.718$ & $\mathrm{P}=0.000^{*}$ \\
\hline
\end{tabular}

Note: * significantly different

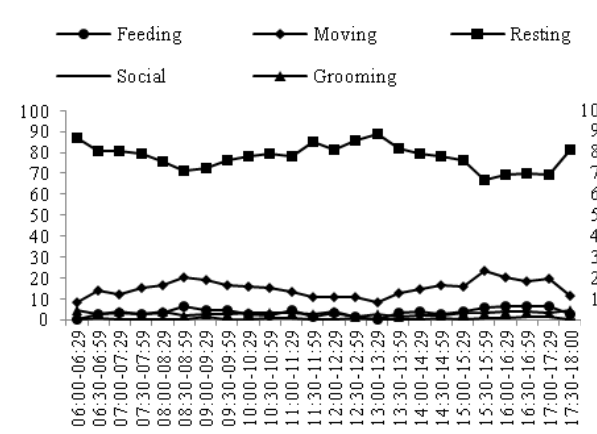

$\mathbf{A}$

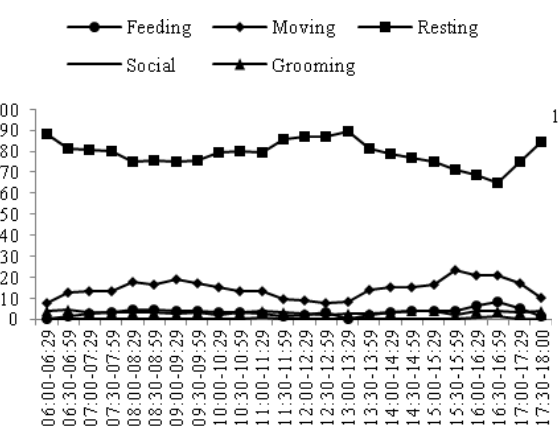

B

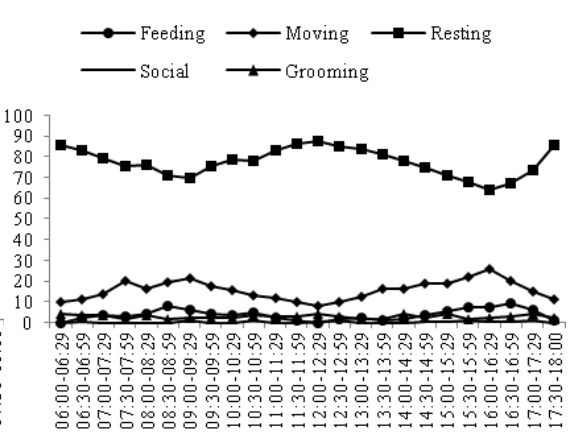

C

Figure 5. Pattern of Ailurops melanotis daily activities of females (A), males (B) and sub adult (C) on Salibabu Island

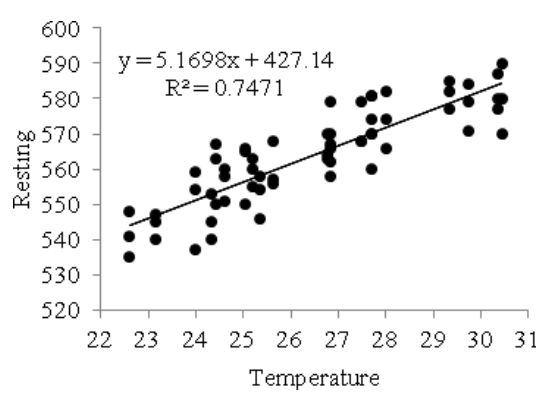

$\mathbf{A}$

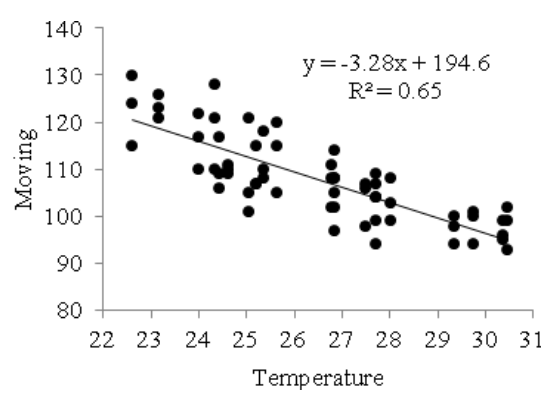

$\mathbf{B}$

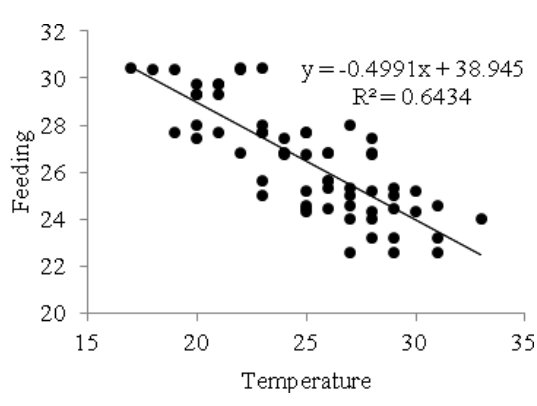

C

Figure 6. Correlation between temperature and activity. A. Resting, B. Moving, C. Feeding

\section{Temperature and humidity}

The average temperature at the study site was $26,45^{\circ} \mathrm{C}$ with the highest temperature $32,10^{\circ} \mathrm{C}$ and the lowest $21,20^{\circ} \mathrm{C}$, with an average humidity of $86.65 \%$. Based on correlation analysis it was found that temperature has a strong positive correlation with resting; $\left(\mathrm{R}=0.864 . \mathrm{R}^{2}=\right.$ 0.75). Conversely, temperature shows a strong negative correlation with feeding and moving activities (temperature 
and feeding: $\mathrm{R}=-0.802 . \mathrm{R}^{2}=0.6434$; temperature and moving: $\left.R=-0.809 R^{2}=0.65\right)$ (Figure 6).

\section{Dietary items}

The talaud bear cuscus was observed to consume 22 species in its daily diet consisting of 20 tree species and 2 liana species (Table 3 ). The 5 highest species in frequency and the amount of time allocation are Merremia peltata $22.46 \%(\mathrm{n}=335, \mathrm{f}=35)$, Canarium asperum $17.35 \%(\mathrm{n}=$ $275, \mathrm{f}=24)$, Cananga odorata $12.49 \%(\mathrm{n}=198, \mathrm{f}=17)$, Aglaia silvestris $9.02 \%(\mathrm{n}=143, \mathrm{f}=35)$ and Palaquium obovatum $7 \%(\mathrm{n}=111, \mathrm{f}=10)$. Cuscus fed mainly on young leaves $(57.48 \%$ of their diet) followed by petioles (leaf stalk) (17.60\%), mature leaves $(15.33 \%)$, bud $(7.19 \%)$, flowers $(1.32 \%)$ and unripe fruit $(1.07 \%)$.

The 5 species with the highest level of preference based on the Neu index were Merremia peltata $(\mathrm{w}=2.88)$, Palaquium obovatum $(\mathrm{w}=2.47)$, Cananga odorata $(\mathrm{w}=$ 2.26), Aglaia silvestris ( $\mathrm{w}=2,25)$, and Macaranga hispida $(\mathrm{w}=1.73)($ Table 4$)$.

\section{Discussion \\ Time budget}

The talaud bear cuscus (A.melanotis) spend the most time resting. This was similar to the study of the Sulawesi bear cuscus (Ailurops ursinus) in Tangkoko Nature Reserve, North Sulawesi, conducted by Dwiyahreni et al. (1999), who found that resting activity was $63.4 \%$ and also Talumepa et al. (2016) who found that resting activity was $56.86 \%$. Likewise, with the research of Nugraha and Mustari (2017) who discovered the A. ursinus in Tanjung Peropa, Southeast Sulawesi, spent of $89.05 \%$ for resting.

Hume (1999) explained that the allocation of time for small mammal activities clearly depends on the digestive dynamics of the species. The high allocation at rest may be related to metabolic rate and energy conservation, so resting is an advantage because it reduces energy requirements and food intake (Boyle 1999). This is in accordance with the opinion of Nie et al. (2015) which states that arboreal folivorous animals show a number of energy-saving characteristics. The fact that a lot of wildlife consumes a high proportion of resting activities and seems to do nothing can be considered an adaptive strategy, because rest periods may be important for digestion, energy conservation or avoiding predators (Dawkins, 1988). A series of behavioral, morphological, and physiological factors including a reduction in the level of physical activity and high metabolic activity, can contribute to low energy expenditure (Nie et al. 2015). In addition, high rest periods may also be related to torpor activity reported in several marsupial species specifically the genus Diprotodontia (Geiser 1994; Geiser et al. 2008; Geiser Fritz and Körtner 2008). Although this still needs further investigation, as Geiser Fritz and Körtner (2008) stated that there has been no observation of torpor activity in the Phalangeridae family, although there is a similar pattern of torpor activity in some marsupial families and seems to be influenced by phylogenetics (Geiser 1994).

The overall proportion of moving activity is only $<15 \%$ of total activity. The cuscus moved for foraging or there were disturbances such as strong winds and rain or feel threatened by the presence of humans. The moving period for foraging can last long, while if there was a threat such as the presence of humans, the cuscus moved in hiding and then showed a frozen position (Nugraha and Mustari 2017). The cuscus moved quadrupedally and used its prehensile tail to hang when changing branches. Locomotion mechanisms like this are specialties that benefit arboreal animals that can minimize energy in moving (Lammers and Biknevicius 2004; Rupert et al. 2014). While for grooming (auto grooming) activity occurs when cuscus resting or will moving, or if there were disturbances such as the presence of ants and other insects. This is common, given that grooming (auto grooming) was a normal part of the repertoire of behavior of various animals and usually functions to clean the surface of animals from parasites (Breed and Moore 2012). The smallest proportion of activity observed was social activity The highest social activity was in females, then sub adult and the lowest was males. Low social activity may be related to solitary behavior of cuscus (Talumepa et al. 2016; Nugraha and Mustari 2017).

In this study, cuscus is often found in pairs or groups. Although there is no mention of the number of frequencies, Dwiyahreni et al. (1999) in their study of A. ursinus found 55 individuals in pairs, 33 in groups and only 17 solitary individuals. This was different from what was stated by Grezimeck (2004) and Mckay and Winter (1989) which states that the majority of species in the Phalangeridae family are solitary.

Based on the Mann Whitney U test, it was found that the time allocation for moving and feeding activities in sub-adult was significantly higher than adult males, whereas the allocation of resting activities in adult male was higher than sub-adult. Ladine (1995) stated that in mammals it is common for young individuals to be active in a different period from adult individuals. This related to the high level of curiosity, play and high exploration in subadult individuals (Coppinger and Smith 1990; Janson and Schaik 1993; Johnson and Wilbrecht 2011). While in certain species, behavior in the adult phase showed a pattern that has been adjusted to a stable niche (Coppinger and Smith1990).

\section{Activity pattern}

Actually, there are still doubts about whether Sulawesi cuscus is nocturnal or diurnal. Jackson (2003) and Nowak (2018) citing Dwiyahreni et al. (1999) stated that the $A$. ursinus seems to be diurnal. While Feldhamer et al. (2007) stated that almost all Phalangeridae are nocturnal. However, Dwiyahreni et al. (1999) reported that they themselves were not sure whether the feeding activity of Sulawesi bear cuscus was only limited during the day, because based on observation, cuscus moved after dark. Through their research, Dwiyahreni et al. (1999) even suspect that there is a possibility that the activity of $A$. ursinus is spread throughout the 24-hour cycle, and this remains to be investigated. In this study, it was found that A. melanotis also moved at night, even in some observations, cuscus moved throughout the night and 
would rest before morning. This cathemeral activity was also reported in several marsupial species such as Dendrolagus lumholtzi, Sminthopsis and Phascolarctos cinereus (Lessiak 2014; Arrese et al. 2007; Kirk 2006), while Tarsipes rostratus were reported to be nocturnal/ crepuscular (Bradshaw et al. 2007).

Table 3. Dietary items and part of plants eaten by Ailurops melanotis on the Salibabu island

\begin{tabular}{|c|c|c|c|c|c|c|c|c|c|c|}
\hline \multirow{3}{*}{ Species } & \multirow{3}{*}{ Family } & \multirow{3}{*}{$\mathbf{n}$} & \multirow{3}{*}{ f } & \multicolumn{6}{|c|}{ Parts ate } & \multirow{3}{*}{$\begin{array}{c}\text { Total } \\
\%\end{array}$} \\
\hline & & & & \multicolumn{4}{|c|}{ Leaves } & \multirow{2}{*}{ Flowers } & \multirow{2}{*}{$\begin{array}{c}\text { Unripe } \\
\text { fruit }\end{array}$} & \\
\hline & & & & Young & Mature & Petioles & Bud & & & \\
\hline Aglaia silvestris & Meliaceae & 143 & 13 & 7.44 & 1.07 & & 0.50 & & & 9.02 \\
\hline Ailanthus integrifolia & Simaroubaceae & 20 & 2 & 1.26 & & & & & & 1.26 \\
\hline Albizia saponaria & Fabaceae & 27 & 4 & 1.70 & & & & & & 1.70 \\
\hline Calophyllum soulattri & Calophyllaceae & 6 & 1 & 0.38 & & & & & & 0.38 \\
\hline Cananga odorata & Annonaceae & 198 & 17 & 7.07 & 4.10 & & & 1.32 & & 12.49 \\
\hline Canarium asperum & Burseraceae & 275 & 24 & 12.93 & 3.47 & & & & 0.95 & 17.35 \\
\hline Canarium balsamiferum & Burseraceae & 78 & 6 & 3.60 & 1.20 & & & & 0.13 & 4.92 \\
\hline Dalbergia ferruginea & Fabaceae & 75 & 9 & 3.85 & & & 0.88 & & & 4.73 \\
\hline Dracontomelon mangiferum & Anacardiaceae & 13 & 1 & 0.63 & 0.19 & & & & & 0.82 \\
\hline Ficus variegata & Moraceae & 8 & 1 & 0.50 & & & & & & 0.50 \\
\hline Gnetum gnemon & Gnetaceae & 5 & 1 & 0.32 & & & & & & 0.32 \\
\hline Macaranga tanarius & Euphorbiaceae & 49 & 5 & 3.09 & & & & & & 3.09 \\
\hline Mallotus tiliifolius & Euphorbiaceae & 30 & 3 & 1.26 & & & 0.63 & & & 1.89 \\
\hline Merremia peltata & Convolvulaceae & 356 & 35 & & & 17.60 & 4.86 & & & 22.46 \\
\hline Palaquium obovatum & Sapotaceae & 111 & 10 & 3.47 & 3.34 & & 0.19 & & & 7.00 \\
\hline Pimelodendron amboinicum & Euphorbiaceae & 17 & 3 & 1.07 & & & & & & 1.07 \\
\hline Polyalthia celebica & Annonaceae & 3 & 1 & 0.19 & & & & & & 0.19 \\
\hline Pometia coriaceae & Sapindaceae & 26 & 3 & 1.51 & & & 0.13 & & & 1.64 \\
\hline Pterospermum celebicum & Sterculiaceae & 31 & 3 & 1.58 & 0.38 & & & & & 1.96 \\
\hline Syzygium acuminatissimum & Myrtaceae & 44 & 4 & 2.02 & 0.76 & & & & & 2.78 \\
\hline Syzygium attenuatum & Myrtaceae & 33 & 3 & 1.83 & 0.25 & & & & & 2.08 \\
\hline Trema orientalis & Cannabaceae & 37 & 5 & 1.77 & 0.57 & & & & & 2.33 \\
\hline Total & & 1585 & 154 & 57.48 & 15.33 & 17.60 & 7.19 & 1.32 & 1.07 & 100 \\
\hline
\end{tabular}

Note: $\mathrm{n}=$ The amount of time in consumption of each type of dietary items (minute), $\mathrm{f}=$ consumption frequency (times)

Table 4. Index of dietary preferences (Neu index)

\begin{tabular}{|c|c|c|c|c|c|c|c|c|}
\hline Species of plant & $\mathbf{a}$ & $\mathbf{p}$ & $\mathbf{n}$ & $\mathbf{u}$ & e & $\mathbf{w}$ & b & Ranking \\
\hline Aglaia silvestris & 10 & 0.04 & 13 & 0.08 & 5.79 & 2.25 & 0.10 & 4 \\
\hline Ailanthus integrifolia & 6 & 0.02 & 2 & 0.01 & 3.47 & 0.58 & 0.03 & 12 \\
\hline Albizia saponaria & 15 & 0.06 & 4 & 0.03 & 8.68 & 0.46 & 0.02 & 18 \\
\hline Calophyllum soulattri & 6 & 0.02 & 1 & 0.01 & 3.47 & 0.29 & 0.01 & 20 \\
\hline Cananga odorata & 13 & 0.05 & 17 & 0.11 & 7.53 & 2.26 & 0.10 & 3 \\
\hline Canarium asperum & 50 & 0.19 & 24 & 0.16 & 28.95 & 0.83 & 0.04 & 8 \\
\hline Canarium balsamiferum & 14 & 0.05 & 6 & 0.04 & 8.11 & 0.74 & 0.03 & 9 \\
\hline Dalbergia ferruginea & 12 & 0.05 & 9 & 0.06 & 6.95 & 1.30 & 0.06 & 7 \\
\hline Dracontomelon mangiferum & 3 & 0.01 & 1 & 0.01 & 1.74 & 0.58 & 0.03 & 13 \\
\hline Ficus variegata & 3 & 0.01 & 1 & 0.01 & 1.74 & 0.58 & 0.03 & 14 \\
\hline Gnetum gnemon & 12 & 0.05 & 1 & 0.01 & 6.95 & 0.14 & 0.01 & 22 \\
\hline Macaranga hispida & 5 & 0.02 & 5 & 0.03 & 2.89 & 1.73 & 0.08 & 5 \\
\hline Mallotus tiliifolius & 11 & 0.04 & 3 & 0.02 & 6.37 & 0.47 & 0.02 & 17 \\
\hline Merremia peltata & 21 & 0.08 & 35 & 0.23 & 12.16 & 2.88 & 0.13 & 1 \\
\hline Palaquium obovatum & 7 & 0.03 & 10 & 0.06 & 4.05 & 2.47 & 0.11 & 2 \\
\hline Pimelodendron amboinicum & 15 & 0.06 & 3 & 0.02 & 8.68 & 0.35 & 0.02 & 19 \\
\hline Polyalthia celebica & 3 & 0.01 & 1 & 0.01 & 1.74 & 0.58 & 0.03 & 15 \\
\hline Pometia coriaceae & 8 & 0.03 & 3 & 0.02 & 4.63 & 0.65 & 0.03 & 10 \\
\hline Pterospermum celebicum & 9 & 0.03 & 3 & 0.02 & 5.21 & 0.58 & 0.03 & 16 \\
\hline Syzygium acuminatissimum & 29 & 0.11 & 4 & 0.03 & 16.79 & 0.24 & 0.01 & 21 \\
\hline Syzygium attenuatum & 8 & 0.03 & 3 & 0.02 & 4.63 & 0.65 & 0.03 & 11 \\
\hline Trema orientalis & 6 & 0.02 & 5 & 0.03 & 3.47 & 1.44 & 0.07 & 6 \\
\hline Total & 266 & 1.00 & 154 & 1.00 & 154 & 22.00 & 1.00 & \\
\hline
\end{tabular}

Note: $\mathrm{a}=$ amount of availability, $\mathrm{p}=$ proportion, $\mathrm{n}=$ Frequency, $\mathrm{u}=$ proportion of presence frequency, $\mathrm{e}=$ expectation value, $\mathrm{w}=$ preference index, $\mathrm{b}=$ standardized preference index. 
However, the study of Nawrot et al. (2019) found no tapetum lucidum in the eyes of $A$. ursinus. Tapetum lucidum as a biological reflector system, is a feature of vertebrate eyes and serves to reflect photons to the retina thereby increasing visual sensitivity at low light levels, this is an advantage for nocturnal animals (Ollivier et al. 2004; Kay et al. 2004). These findings, seem to confirm that the A. ursinus was a diurnal species. However, some species that are classified as nocturnal and crepuscular are also noted not to have tapetum lucidum such as Macropus rufus (Ollivier et al. 2004) and Tarsius (Kay et al. 2004; Kirk and Kay 2004). Furthermore, Kirk and Kay (2004) explain that many mammals that are regularly active during the day retain tapeta, including many diurnal strepsirrhine, cathemeral carnivores, and cathemeral ungulate. There are several hypotheses that explain how nocturnal animals can use light with the absence of a tapetum lucidum, one of which is morphological adaptation (large eye size) (Ollivier et al. 2004; Kay et al. 2004) and evolution of the fovea and macula lutea in Tarsiers (Kirk and Kay 2004).

Furthermore, according to Donati et al (2006) and Eppley et al. (2016), there are at least 4 hypotheses proposed to explain the determinants for cathemeral activity: thermoregulatory benefits, anti-predator strategy, competition avoidance and metabolic dietary-related needs. While based on Diete et al (2017), variation, fixity, and plasticity in activity patterns can be influenced by factors such as season and habitat (temporal resource availability). Based on this study, the assumption that the possibility of talaud bear cuscus activity may spread over 24 hours might be driven by the thermoregulatory benefits and the metabolic dietary-related needs. While the antipredator strategy and competition avoidance may not be the cause, given the absence of natural predators, and the talaud bear cuscus is the only arboreal folivores species found on Salibabu Island, which means that no other species occupy the same food niche as the talaud bear cuscus. But this still requires further research, considering that no nutritional feeding, rainfall, phenology, and moonlight data were collected.

Based on observations, it was found that the activity of moving and feeding on $A$. melanotis occurs highest in the afternoon while the highest time to rest during the day. High feeding activity in the afternoon was also observed in A. ursinus, where Dwiyahreni et al. (1999) stated that a significant increase in feeding activities in the afternoon allows more efficient use of time if digestion proceeds during the night. While high resting activities during the day may be related to digestion processes and temperature. Lawrance (1990) states that temperature is usually very influential on mammalian activity. Even some species can adapt their space use and distribution of activity in response to temperature changes (Brodie et al. 2017).

Based on correlation analysis it was found that temperature has a strong positive correlation with resting. This indicates that high temperatures during the day, causing cuscus to reduce activity and prefer to rest. Vieira et al. (2017) in their study of Gracilinanus agilis found that there was a relationship between temperature and activity, according to them the pattern shows the importance of temperature in marsupial activities, and such behavior allows marsupials to minimize energy loss due to the thermoregulation process. In addition, MacLennan (1984) also revealed that animals can reduce their activity patterns to maximize energy expenditure. Conversely, temperature shows a strong negative correlation with feeding and moving activities. This shows that the higher the temperature, the lower the activity of moving and feeding activities, and vice versa.

\section{Diet}

Cuscus on Salibabu Island consumed 30.14\% (22 species) of a total of 73 plant species based on vegetation analysis. Although cuscus consumes a variety of items, there is a selective tendency towards the species eaten. Diet selectivity in animals can be associated with the digestive system. Hume (1999) explains that arboreal folivorous marsupial species are cecum fermenters (a process of digestion occurring in the cecum), including the Phalangeridae family. With this digestive system, animals will avoid species with high lignin content (Hume 1999), and choose high-nutrient food items (Munks and Green 1995).

In general, the highest type of species is consumed based on frequencies, relatively the same as the preference based on the Neu index. The difference is only found in a few species. Where the highest species consumed were $M$. peltata, C. asperum, and C. odorata. While based on the Neu index the most preferred species are M. peltata, $P$. obovatum, and $C$. odorata. During the observation, cuscus only consumed young fruit from $C$. asperum and $C$. balsamiferum, in several observations, cuscus was seen reaching the fruit of Gnetum gnemon and Pometia coriacea but not consuming it. Differences in preferences based on the Neu index and results of the duration of feeding use may be related to the temporal availability of young leaves (Dwiyahreni et al. 1999), or caused by differences in the amount of availability of dietary species based on vegetation analysis, which is a divider for calculating the Neu index.

Besides species, the talaud bear cuscus also shows preference for the part of the species eaten. The cuscus prefers to consume young leaves $(57.48 \%)$ rather than mature leaves (15.33\%). The same is found in Ailurops ursinus where consumption of young leaves is $54.4 \%$ (Dwiyahreni et al. 1999). By consuming young leaves that have higher water and energy content than old leaves, cuscus can increase energy, nutrition and water intake as a whole (Munks and Green 1995). In addition, young leaves have a high content of several important nutrients such as crude protein and phosphorus and low cell walls of polysaccharides and lignin (Hume 1999). But in some species, cuscus is also seen consuming mature leaves. According to Hume (1999) the selection of old leaves as part of a diet may be due to the limited availability of young leaves, while Chen and Poland (2009) in their study of Fraxinus pennsylvanica, found that older leaves are 
more nutritious with amino acids and a greater protein ratio than young leaves, especially when the tree is in the shade.

In general, the low allocation of feeding time in talaud bear cuscus may be related to basal metabolic rate, as explained by Nagy and Martin (1985) that arboreal folivores mammals have low basal metabolic rates compared to non-arboreal mammals with almost the same body size, even arboreal folivores mammals tend to have lower basal metabolic rates than non-folivorous arboreal animals. This gives two advantage, first, nutritional needs are reduced, following a reduction in the amount of food needed. Second, the overall consumption of plant secondary metabolites (such as phenolic, tannin and alkaloid) also decreases as a direct consequence of reduced food intake (Boyle 1999). In talaud bear cuscus, the allocation of low feeding time is compensated by high resting activities. In addition to maximizing energy use, this may be related to the strategy of 'maximizing retention'. Cork (1996) state that for mammals eating highfibre diets, like tree foliage, energy requirements can be met by a 'retention-maximizing' strategy of delaying the passage of food through the gut to maximize extent of digestion by facilitating microbial degradation of dietary cell walls.

This is common for arboreal folivores species that adapt digestion and feeding behavior to maximize energy and nutrient intake from low-quality diet as one of the characteristics of energy savings (Munks and Green 1995). As is known in the species cecum fermenter or coloncecum fermenters, dissolved substances and particles are deposited selectively in the cecum and colon, while large particles high in lignin fibers are excreted rapidly. This mechanism of colon separation minimizes nitrogen loss and maintains easily digestible parts, thus, this process can affect the amount of food consumed (Cork 1996).

Overall the activity of the talaud bear cuscus is dominated by resting. The daily activities pattern showed that the cuscus starts actively in the morning and rests during the day, then shows an increase in activity in the afternoon. The difference in activity over a period of time is caused by environmental factors in this case temperature and physiological factors of digestion which are typical in arboreal marsupial animals. Talaud bear cuscus is a follivore that consumes more than $90 \%$ of leaves in its total daily diet (young leaves, old leaves, shoots, and leaf stalks) and the rest is flowers and fruit with a small percentage. In general, cuscus prefers to consume young leaves in its diet. Although cuscus consumes a variety of plant species, there is a preference for the type of feed. This preliminary data about the behavior, activity patterns, and diet of talaud bear cuscus, in general, can be used as supporting information in cuscus conservation efforts, especially habitat management related to the availability of feed resources. This information could be valuable for researchers to determine the time of the survey and to understand the general behavior and ecology of this species. Further research focusing on nightly data collection is very important to know how much cuscus activity is spread over 24 hours and what factors that affect it.

\section{REFERENCES}

Altmann J. 1974. Observational Study Of Behavior Sampling Method. National Academy Press. Washington DC.

Arrese C, Dunlop SA, Harman AM, Braekevelt CR, Ross WM, Shand J, Beazley LD. 1999. Retinal structure and visual acuity in a polyprotodont marsupial, the fat-tailed dunnart (Sminthopsis crassicaudata). Brain Behav Evol 53 (3): 111-126. DOI:10.1159/000006588.

Boyle RR. 1999. The metabolic fate of dietary terpenes in folivorous marsupials. [Dissertation]. University of Tasmania, Hobart, Australia.

Bradshaw SD, Phillips RD, Tomlinson S, Holley RJ, Jennings S, Bradshaw FJ. 2007. Ecology of the honey possum, Tarsipes rostratus, in Scott National Park, Western Australia. Aust Mammal 29 (1): 2538. DOI: 10.1071/AM07003.

Breed MD, Moore J. 2012. Animal Behavior. Academic Press, USA.

Brodie JF, Strimas-Mackey M, Mohd-Azlan J, Granados A, Bernard H, Giordano AJ, Helmy OE. 2017. Lowland biotic attrition revisited: Body size and variation among climate change 'winners' and 'losers'. Proc R Soc Lond B Biol Sci 284 (1847): 1-5. DOI:10.1098/rspb.2016.2335.

CITES [Convention on International Trade in Endangered Species of Wild Fauna and Flora]. http://cites.org/eng/app/appendices.php. [24 November 2014]

Chen Y, Poland TM. 2009. Interactive influence of leaf age, light intensity, and girdling on green ash foliar chemistry and emerald ash borer development. J Chem Ecol 35 (7): 806-815. DOI:10.1007/s10886-009-9661-1.

Coppinger RP, Kay SC. 1990. A model for understanding the evolution of mammalian behavior. In: Genoways H (eds.) Current Mammalogy Volume 2. Plenum Press, USA.

Cork SJ. 1996. Optimal digestive strategies for arboreal herbivorous mammals in contrasting forest types: Why Koalas and Colobines are different. Aust J Ecol 21 (1): 10-20. DOI:10.1111/j.14429993.1996.tb00581.x.

Dawkins MS. 1988. Behavioural Deprivation: A Central Problem in Animal Welfare. Appl Anim Behav Sci 20 (3-4): 209-225. DOI:10.1016/0168-1591 (88)90047-0.

Diete RL, Meek PD, Dickman CR, Lisle A, Leung LK-P. 2017. Diel activity patterns of northern Australian small mammals: variation, $\begin{array}{llll}\text { fixity, and plasticity. J. Mammal } 98 \text { (3): 848-857. } & \text {. }\end{array}$ DOI:10.1093/jmammal/gyx003.

Donati G, Baldi N, Morelli V, Ganzhorn JU, Borgognini-Tarli SM. 2009. Proximate and ultimate determinants of cathemeral activity in brown lemurs. Anim Behav 77 (2): 317-325. DOI: 10.1016/j.anbehav.2008.09.033.

Dwiyahreni A, Kinnaird M, O'Brien T, Supriatna J, Andayani N. 1999. Diet and activity of the bear cuscus, Ailurops ursinus, in North Sulawesi, Indonesia. J Mammal 80 (3): 905-912. DOI: $10.2307 / 1383259$.

EDGE [Evolutionarily Distinct and Globally Endangered Species]. 2007. http://www.edgeofexistence.org/mammals/species_info.php?id=1401. Accessed 24 November 2014.

Eppley TM, Watzek J, Ganzhorn JU, Donati G. 2016. Predator avoidance and dietary fibre predict diurnality in the cathemeral folivore Hapalemur meridionalis. Behav Ecol Sociobiol 71 (1): 1-12. DOI: $10.1007 / \mathrm{s} 00265-016-2247-3$.

Feldhamer GA, Drickamer LC, Vessey SH, Merritt JF, Krajewski C. 2007. Mammalogy: Adaptation, Diversity, Ecology. 3rd ed. Johns Hopkins University Press, Baltimore.

Flannery T, Helgen K. 2016. Ailurops melanotis. The IUCN Red List of Threatened Species 2016: e.T136218A21949526. DOI: 10.2305/IUCN.UK.20162.RLTS.T136218A21949526.en. [14 June 2019].

Geiser F. 1994. Hibernation and daily torpor in marsupials: a review. Aust J Zool 42 (1):1-16. DOI:10.1071/ZO9940001.

Geiser F, Christian N, Cooper CE, Körtner G, Mcallan B, Pavey C, Turner JM, Warnecke L, Willis CKR, Brigham RM. 2008. Torpor in marsupials: recent advances. In: Lovegrove $\mathrm{BG}, \mathrm{McKechnie} \mathrm{AE}$ (eds.). Hypometabolism in Animals: Hibernation, Torpor and Cryobiology. Interpak Books, South Africa.

Geiser F, Körtner G. 2010. Hibernation and daily torpor in Australian mammals. Aust Zoologist 35 (2): 204-215. DOI: 10.7882/AZ.2010.009.

Grezimeck B. 2004. Grezimeck's Animals Encylopedia 2nd edition, vol. 13. Mammals II. Thomson Gale, Canada. 
Groves CP. 2005. Order Diprotodontia. In: Wilson DE, Reeder DM (Eds.). Mammal Species of the World: A Taxonomic and Geographic Reference. 3rd ed. Johns Hopkins University Press, Baltimore.

Handayani SK, Kunda RM. 2019. Identifikasi Jenis-Jenis Tumbuhan Sebagai Pakan Kuskus (Phalangeridae) Asal Maluku di Taman Nasional Manusela Bagian Utara Kabupaten Maluku Tengah. J Matematika, Sains, dan Teknologi 20 (1): 9-19. [Indonesian]

Heinsohn TE. 2010. Marsupials as introduced species: Longterm anthropogenic expansion of the marsupial frontier and its implication for zoogeographic interpretation. In: Haberle, Simon G (eds.). 2010 Altered Ecologies: Fire, climate and human influence on terrestrial landscapes.Terra Australis 32. Canberra, Australia (AU). ANUE Press, Canberra.

Helgen KM, and Jackson SM. 2015. Family Phalangeridae (Cuscuses, Brush-tailed Possums and Scaly-tailed Possum). In: Wilson DE, Mittermeier RA (Eds.). Handbook of The Mammals of the World, Vol. 5: Monotremes and Marsupials. Lynx Edicions, Barcelona.

Hume ID. 1999. Marsupial Nutrition. Cambridge Univ Press. New York.

Inoue Y, Sinun W, Okanoya K. 2016. Activity budget, travel distance, sleeping time, height of activity and travel order of wild East Bornean Grey gibbons (Hylobates funereus) in Danum Valley Conservation Area. Raffles B Zool 64: 127-138.

IUCN [International Union for Conservation of Nature]. 2008. http://www.iucnredlist.org/static/categories_criteria_3_1. December 2018]

Jackson S. 2003. Australian Mammals: Biology and Captive Management. CSIRO Publishing, Australia.

Janson CH, Schaik CP. 1993. Ecological risk aversion in juvenile primates: slow and steady wins the race. In: Pereira ME, Fairbanks LA (eds.). Juvenile primates: Life history, development, and behavior. University of Chicago Press, Chicago.

Johnson C, Wilbrecht L. 2011. Juvenile mice show greater flexibility in multiple-choice reversal learning than adults. Dev Cogn Neurosci 1 (4): 540-551. DOI:10.1016/j.den.2011.05.008.

Kay RF, Campbell VM, Rossie JB, Colbert MW, Rowe TB. 2004 Olfactory Fossa of Tremacebus harringtoni (Platyrrhini, Early Miocene, Sacanana, Argentina): Implications for Activity Pattern. Anat Rec A Discov Mol Cell Evol Biol 281 (1):1157-72. DOI: 10.1002/ar.a.20121.

Kealy S. 2018. Modelling early modern human dispersal patterns through the Wallacean Archipelago. [Dissertation]. Australian National University, Canberra, Australia.

Kirk EC. 2006. Eye Morphology in Cathemeral Lemurids and Other Mammals. Folia Primatol 77:27-49. DOI: 10.1159/000089694.

Kirk EC, Kay RF. 2004. The evolution of high visual acuity in the Anthropoidea. In: Ross CF, Kay RF (eds.). Anthropoid Origins: New visions. Kluwer/Plenum, New York.

Nawrot JEK, Harłajczuk KG, Darska M, Barszcz K, Janeczek M. 2019. Microstructure of the eye tunics, eyelids and ocular glands of the Sulawesi bear cuscus (Ailurops ursinus Temminck, 1824) (Phalangeridae: Marsupialia) based on anatomical, histological and histochemical studies. Acta Zool 100 (2): 182-210. DOI: $10.1111 /$ azo.12251.

Krebs JR, Davies N B. 1987. An Introduction to Behavioural Ecology. 3rd ed. Blackwell Science, London.

Krebs CJ. 1989. Ecological Methodology. Harper and Row, New York.

Ladine TA. 1995. Ecology of co-occurring populations of Virginia opossums (Didelphis virginiana) and raccoons (Procyon lotor). [Dissertation] The University of Memphis, Tennessee, USA

Lammers AR, Biknevicius AR. 2004. The biodynamics of arborea locomotion: the effects of substrate diameter on locomotor kinetics in the gray short-tailed opossum (Monodelphis domestica). J Exp Biol 207: 4325-4336. DOI: 10.1242/jeb.01231.

Lessiak A. 2014. Methods for the Effective Care and Rehabilitation of Captive Lumholtz's Tree-kangaroos. Independent Study Project (ISP) Collection. 1753. https://digitalcollections.sit.edu/isp collection/1753

Lawrance WF. 1990. Effects of weather on marsupial folivore activity in a north Queensland upland tropical rainforest. Aust Mammal 13: 41-47.

MacLennan DG. 1984. The feeding behaviour and activity patterns ofthe brushtail possum, Trichosurus vulpecula, in an open eucalypt woodland in Southeast Queensland. In: Smith AP, Hume ID (eds.) Possums and Gliders. Surrey Beatty Assoc. with the Australian Mammal Society, Chipping Norton, NSW.

Mckay GM, Winter JW. 1989. Phalangeridae. In: Walton DW, Richardson BJ (eds.). Fauna of Australia. Volume 1B. Mammalia. AGPS, Canberra.
Milis DS, Marchant-Forde JN, McGreevy PD, Morton DB, Nicol ChJ, Philips CJC, Sandoe P, Swaisgood RR. 2010. The Encyclopedia of Applied Animal Behaviour And Welfare. CAB International, London.

Milton K. 1999. Nutritional Characteristics of Wild Primate Foods: Do the Diets of Our Closest Living Relatives Have Lessons for Us?. Nutr J 15 (6): 488-498. DOI: 10.1016/S0899-9007 (99)00078-7.

Munks SA, Green B. 1995. Energy allocation for reproduction in a marsupial arboreal folivore, the common ringtail possum (Pseudocheirus peregrinus). Oecologia 101 (1):94-104. DOI: 10.1007/BF00328905

Nagy KA, Martin R. (1985). Field metabolic rate, water influx, food consumption and time budget of koalas (Phascolarctos cinereus). Aust J Zool 33 (5): 655-665. DOI: 10.1071/ZO9850655.

Nelson SL, Miller MA, Heske EJ, Fahey Jr GC. 2000. Nutritional Quality of Leaves and Unripe Fruit Consumed as Famine Foods by the Flying Foxes of Samoa. Pac Sci 54 (4): 301-311.

Nie Y, Speakman JR, Wu Q, Zhang C, Hu Y, Maohua X, Yan L, Hambly C, Wang L, Wei W, Zhang J, Wei F. 2015. Exceptionally low daily energy expenditure in the bamboo-eating giant panda. Science 349: 171-174.

Nowak RM. 2018. Walker's Mammals of the World: Monotremes, Marsupials, Afrotherians, Xenarthrans, and Sundatherians. Johns Hopkins University Press, Baltimore, MD

Nugraha R, Mustari A H. 2017. Habitat Characteristics and Diet of Bear Cuscus (Ailurops ursinus) in Tanjung Peropa Wildlife Reserve, Southeast Sulawesi. J Wasian 4 (2): 55-68. [Indonesian]

Oates JF, Waterman PG, Choo G M. 1980. Food selection by South Indian leaf-monkey, Presbytis johnii, in relation of leaf chemistry. Oecologia, 45 (1):45-56. DOI: 10.1007/BF00346706.

Ollivier FJ, Samuelson DA, Brooks DE, Lewis PA, Kallberg ME, Komaromy AM. 2004. Comparative morphology of the tapetum lucidum (among selected species). Vet Ophthalmol 7 (1): 1122. DOI:10.1111/j.1463-5224.2004.00318.x.

Reed JM. 2002. Animal behavior as a tool in conservation biology. In: Aguirre AA, Ostfeld RS, House CA, Tabor GM, Pearl MC (eds.). Conservation Medicine: Ecological Health in Practice. Oxford University Press, Oxford.

Ruedas LA, Morales JC. 2005. Evolutionary relationships among genera of Phalangeridae (Metatheria: Diprotodontia) inferred from mitochondrial DNA. J Mammal 86 (2): 353-365.

Rupert JE, Schmidt EC, Moreira-Soto A, Herrera BR, Vandeberg JL, Butcher MT. 2014. Myosin Isoform Expression in the Prehensile Tails of Didelphid Marsupials: Functional Differences Between Arboreal and Terrestrial Opossums. Anat Rec 297: 1364-1376. DOI: $10.1002 / a r .22948$

Riley J. 2002. Mammals on the Sangihe and Talaud Islands, Indonesia, and the Impact of Hunting and Habitat Loss. Oryx 36 (3): 288-296. DOI: $10.1017 / \mathrm{S} 0030605302000510$

Saragih E W, Sadsoeitoeboen M J, Pattiselanno F. 2010. The diet of spotted cuscus (Spilocuscus maculatus) in natural and captivity habitat Nusantara Biosci 2 (2): 78-83 DOI: 10.13057/nusbiosci/n020205.

Sinclair ARE, Fryxell JM, Caughley G. 2006. Wildlife Ecology, Conservation and Management. Second Edition. Blackwell Publishing, Australia.

Smith RJ, Verissimo D, Isaac NJB, Jones KE. 2012. Identifying Cinderella Species: Uncovering Mammals With Conservation Flagship Appeal. Conserv Lett 5 (3): 205-212. DOI: 10.1111/j.1755 263X.2012.00229.x.

Sutherland WJ. 1998. The importance of behavioural studies in conservation biology. Anim Behav 56 (4): 801-809. DOI:10.1006/anbe.1998.0896

Talumepa PAA, Wungow RSH, Poli Z, Rimbing SC. 2016. Tingkahlaku harian kuskus beruang (Ailurops ursinus) di Cagar Alam Tangkoko Batu Angus. J Zootek 36 (1): 174-183. [Indonesian]

Vieira EM, De Camargo NF, Colas PF, Ribeiro JF, Cruz-Neto AP. 2017. Geographic variation in daily temporal activity patterns of a neotropical marsupial (Gracilinanus agilis). PLoS One 12 (1): e0168495. DOI:10.1371/journal.pone.0168495.

Wilson DE, Reeder DM. 2005. Mammal Species of the World. A Taxonomic and Geographic Reference. 3rd ed. Johns Hopkins University Press, Washington DC

Zhou Q, Wei F, Huang C, Li M, Ren B, Luo B. 2007. Seasonal variation in the activity patterns and time budgets of Trachypithecus francoisi in the Nonggang Nature Reserve, China. Int J Primatol 28 (3): 657671. DOI:10.1007/s10764-007-9144-6. 